\title{
Faktor-Faktor Promosi Kenaikan Jabatan, Efektifitas Pembagian Tugas dan Keadilan Pembagian Insentif Yang Mempengaruhi Kepuasan Kerja Terhadap Pegawai Dinas Kesehatan Provinsi Jambi Tahun 2016
}

\author{
Ayu Aztuty Tanjung ${ }^{1}$, Sudiro ${ }^{2}$, Sutopo Patria Jati ${ }^{2}$ \\ 1) Dinas Kesehatan Provinsi Jambi \\ Jenderal A. Yani No. 1 Jambi \\ Telp.(0741)66269,ayuaztuty@yahoo.co.id \\ 2) Fakultas Kesehatan Masyarakat, Universitas Diponegoro, Semarang
}

Title : The Factor of Office Position Raising, Assigment Distribution Effectiveness and The Incentive Equalization That Affects The Working Satisfaction of Health Departement Employoe In 2016

\section{Abstrak}

Untuk meningkatkan laju pembangunan kesehatan di Provinsi Jambi maka harus di topang oleh SDM yang berkualitas sehingga akan meningkatkan kinerja pegawai. Penurunan kinerja bisa diakibatkan karena tidak adanya kepuasan kerja oleh pegawai. Adapun permasalahan yang dihadapi pada Dinas Kesehatan Provinsi Jambi adalah semakin menurunnya indeks kepuasan kerja karyawan dari waktu ke waktu. Maka untuk memberikan kepuasan kerja kepada pegawai maka harus didorong dengan promosi kenaikan jabatan, keadilan pembagian insentif baik secara finansial atau non finanial dan pembagian tugas secara merata. Tujuan penelitian ini adalah untuk mengetahui pengaruh promosi kenaikan jabatan, efektifitas pembagian tugas dan keadilan pembagian insentif terhadap kepuasan kerja pegawai di Kantor Dinkes Provinsi Jambi.

Jenis penelitian merupakan penelitian observasional dengan pendekatan cross sectional. Populasi penelitian adalah karyawan Dinkes Provinsi Jambi berjumlah 277 orang, sedangkan sampel penelitian sebanyak 74 orang. Instrumen penelitian menggunakan kuesioner. Data penelitian diolah secara kuantitatif dengan metode univariat, bivariat dengan uji Chi Square dan analisis multivariat dengan analisis regresi logistik.

Hasil penelitian menunjukkan sebagian besar karyawan Dinkes Provinsi Jambi merasa puas $(56,8 \%)$, promosi kenaikan jabatan dipersepsikan seimbang (50\%), efektivitas pembagian tugas baik $(55,4 \%)$ dan keadilan pembagian insentif baik $(51,4 \%)$. Hasil penelitian menyatakan ada hubungan yang bermakna antara promosi kenaikan jabatan, efektivitas pembagian tugas dan keadilan pembagian insentif dengan kepuasan pegawai Dinkes Provinsi Jambi. Hasil analisis multivariat menunjukkan variabel promosi kenaikan jabatan dan keadilan pembagian insentif secara bersama-sama berpengaruh terhadap kepuasan pegawai Dinkes Provinsi Jambi.

Saran yang dapat direkomendasikan dalam mengelola kepuasan kerja pegawai hendaknya memperhatikan faktor promosi kenaikan jabatan, efektivitas pembagian tugas dan keadilan pembagian insentif.

Kata kunci : Kepuasan Kerja, Promosi Kenaikan Jabatan, Efektivitas Pembagian Tugas, Keadilan pembagian insentif, Dinkes Provinsi Jambi

Referensi : 22 (2000-2013)

\section{Abstract}

To increase the pace of development of health in the province of Jambi it must be in the crutch by qualified human resources that will improve employee performance. The decline in performance can be caused by lack of job satisfaction by employees. The problems faced by the Provincial Health Office of Jambi is a further decline in employee satisfaction index from time to time. So to give you job satisfaction to employees it must be driven by the sale promotion, equity incentive distribution either financially or non finanial and division of tasks evenly. The purpose of this study was to determine the effect of a promotion campaign, the effectiveness of the division of tasks and justice division of incentives on job satisfaction of employees in the Office of the Provincial Health Office of Jambi. 
This type of research is an observational research with cross sectional approach. The study population were employees of the Provincial Health Office of Jambi amounted to 277 people, while the study sample as many as 74 people. The research instrument used questionnaire. Data were analyzed quantitatively with univariate, bivariate with Chi Square and multivariate analysis with logistic regression analysis.

The results show most employees Jambi Provincial Health Office is satisfied (56.8\%), sale promotion perception balanced (50\%), the effectiveness of the division of tasks well (55.4\%) and the equity incentive distribution well (51.4\%). The study states there is a significant relationship between promotion promotion, the effectiveness of the division of tasks and equity incentive distribution with employee satisfaction Jambi Provincial Health Office. Multivariate analysis showed that variables sale promotions and incentive distribution fairness jointly effect on employee satisfaction Jambi Provincial Health Office.

Suggestions that can be recommended to manage employee satisfaction should take into account the promotion of a promotion, the effectiveness of the division of labor and division of equity incentives.

$\begin{array}{llr}\text { Keywords : } & \text { Job Satisfaction, Increase } \\ & \text { Promotions } & \text { Position, } \\ & \text { Effectiveness Division of } \\ & \text { Labor, Justice incentive } \\ & \text { distribution, Jambi Provincial } \\ & \text { Health Office } & \\ \text { References : } & 22(2000-2013)\end{array}$

\section{Pendahuluan}

Dalam rangka meningkatan pelaksanaan program/kegiatan pemerintah dibidang kesehatan yang berdaya guna, bersih dan bertanggung jawab dalam mencapai tujuan, sasaran dan target indikator dan pembangunan kesehatan yang telah ditentukan dan untuk mendukung pelaksanaan upaya program upaya kesehatan yang efektif dan efisien, maka perlu adanya perencanaan, anggaran data dan informasi yang akurat.

Kebijakan pembangunan kesehatan Provinsi Jambi tidak terlepas dari perkembangan kesehatan secara regional, oleh sebab itu strategi dan kebijakan daerah dibidang kesehatan perlu memperhatikan kondisi dan kecendrungan keadaan kesehatan secara nasional maupun regional dimasa yang akan datang.

Pembangunan kesehatan di Provinsi Jambi secara berangsur-angsur telah berhasil meningkatkan derajat kesehatan masyarakat sepertinya menurunnya status gizi masyarakat serta meningkatkan umur harapan hidup. Untuk meningkatkan laju pembangunan kesehatan maka harus di topang oleh SDM yang berkualitas. SDM yang berkualitas akan meningkatkan kinerja pegawai. Penurunan kinerja bisa diakibatkan karena tidak adanya kepuasan kerja oleh pegawai. Hal ini sejalan dengan penelitian yang dilakukan oleh Indrawati bahwa ada korelasi antara kepuasan dengan kinerja pegawai. ${ }^{(1)}$

Kepuasan kerja pada dasarnya merupakan hal yang bersifat individual. Setiap individu memiliki tingkat kepuasan yang berbeda-beda sesuai dengan keinginan dan sistem nilai yang dianutnya. Untuk memberikan kepuasan kerja kepada pegawai maka harus didorong dengan promosi jabatan. Promosi adalah kemajuan dari seseorang pegawai pada suatu tugas yang lebih baik dipandang dari sudut tanggung jawab yang lebih besar, prestise atau status yang lebih tinggi, kecakapan yang lebih besar dan terutama tambahan pembayaran gaji. ${ }^{(2)}$

Promosi pada dasarnya merupakan peningkatan jabatan maupun pangkat yang merupakan pengembangan pegawai karena dapat memotivasi Pegawai Negeri Sipil untuk lebih meningkatkan kemampuan dan prestasi kerjanya. Promosi dapat didasarkan atas dua pertimbangan. Pertama kecakapan yang penilaian pegawai dilakukan melalui pengamatan oleh atasan yang bersangkutan dan dengan cara menguji pada saat tertentu, sehingga diperoleh sekumpulan nilai yang bisa menjadi pertimbangan dalam menentukan promosi dan yang kedua masa kerjanya (senioritas) yaitu masa kerja pegawai secara terus menerus dalam suatu organisasi atau makin lama masa kerja pegawai menjadi pertimbangan dalam menentukan promosi karena makin banyak pengalaman kerja yang dimiliki. ${ }^{(3)}$ 
Menurut Undang-Undang Republik Indonesia Nomor 5 tahun 2014 tentang Aparatur Sipil Negara (ASN), pangkat dan jabatan adalah:

1) PNS diangkat dalam pangkat dan jabatan tertentu pada Instansi Pemerintah.

2) Pengangkatan PNS dalam jabatan tertentu sebagaimana dimaksud pada ayat (1) ditentukan berdasarkan perbandingan objektif antara kompetensi, kualifikasi, dan persyaratan yang dibutuhkan oleh jabatan dengan kompetensi, kualifikasi, dan persyaratan yang dimiliki oleh pegawai.

3) Setiap jabatan tertentu sebagaimana dimaksud pada ayat (1) dikelompokkan dalam klasifikasi jabatan PNS yang menunjukkan kesamaan karakteristik, mekanisme, dan pola kerja.

4) PNS dapat berpindah antar dan antara Jabatan Pimpinan Tinggi, Jabatan Administrasi, dan Jabatan Fungsional di Instansi Pusat dan Instansi Daerah berdasarkan kualifikasi, kompetensi, dan penilaian kinerja.

5) PNS dapat diangkat dalam jabatan tertentu pada lingkungan instansi Tentara Nasional Indonesia dan Kepolisian Negara Republik Indonesia.

6) PNS yang diangkat dalam jabatan tertentu sebagaimana dimaksud pada ayat (5), pangkat atau jabatan disesuaikan dengan pangkat dan jabatan di lingkungan instansi Tentara Nasional Indonesia dan Kepolisian Negara Republik Indonesia.

7) Ketentuan lebih lanjut mengenai pangkat, tata cara pengangkatan PNS dalam jabatan, kompetensi jabatan, klasifikasi jabatan, dan tata cara perpindahan antar Jabatan Administrasi dan Jabatan Fungsional sebagaimana dimaksud pada ayat (1), ayat (2), ayat (3), ayat (4), ayat (5), dan ayat (6) diatur dengan Peraturan Pemerintah. ${ }^{(4)}$

Aspek lain yang berkaitan dengan kepuasan kerja adalah keadilan pembagian insentif. Penelitian yang dilakukan oleh Zaputri dkk menemukan bahwa pembagian insentif finansial berpengaruh positif terhadap kepuasan karyawan. Aspek lain bahwa insentif non finansial juga berpengaruh positif terhadap kepuasan karyawan. ${ }^{(5)}$ $\begin{array}{crr}\text { Efektifitas } & \begin{array}{r}\text { pembagian tugas juga } \\ \text { kepuasan }\end{array} \\ \text { mempengaruhi } & \text { pegawai. }\end{array}$

Berdasarkan Peraturan Gubernur No.30 Tahun 2015 tentang Uraian Tugas dan Fungsi Dinas Provinsi Jambi, Dinas Kesehatan mempunyai tugas melaksanakan urusan pemerintah daerah berdasarkan atas otonomi dan tugas perbantuan di Bidang Kesehatan, untuk melaksanakan tugas sebagaimana yang dimaksud Dinas Kesehatan mempunyai fungsi :

1) Perumusan kebijakan teknis dibidang kesehatan penyelenggaraan urusan pemerintah dan pelayanan umum dibidang kesehatan

2) Pembinaan dan pelakasanaan tugas dibidang kesehatan

3 ) Pelaksanaan tugas lain yang diberikan oleh gubernur sesuai dengan tugas dan fungsinya

Membuat karyawan merasa puas terhadap pekerjaannya, sudah menjadi suatu keharusan bagi perusahaan. Kepuasan kerja sendiri berhubungan erat dengan promosi jabatan, keadilan dalam pemberian kompensasi dan lingkungan kerja fisik. Karyawan dalam bekerja juga memiliki beberapa harapan. Karyawan memiliki harapan bahwa mereka bisa dipromosikan ke jabatan atau posisi yang lebih tinggi. Selain itu karyawan juga mengharapkan pemberian kompensasi (balas jasa) yang diberikan secara adil dan merata. Karyawan juga berharap bahwa mereka juga ikut terlibat dalam mendesain tata letak ruangan kantornya dan mampu dengan bebas menyampaikan aspirasi mereka tentang keluhan-keluhan yang dirasakan terhadap lingkungan kerjanya.

Ketatnya persaingan antar karyawan akan membuat karyawan memikirkan kembali peluang dan kesempatan mereka untuk dipromosikan. Terdapat perbedaan besaran dalam pemberian insentif antara karyawan satu dengan karyawan lain dalam jabatan yang sama akan membuat karyawan merasa adanya ketidakadilan. Karyawan akan memandang adil atau tidak adil dalam pemberian kompensasi berdasarkan pada persepsi mereka. Tidak ada kesempatan yang diberikan bagi karyawan untuk menyampaikan keinginan serta aspirasi 
mereka mengenai tata letak dan desain ruang kerja akan membuat karyawan merasa bahwa mereka tidak mempunyai kontrol terhadap lingkungan kerjanya. Bila keseluruhan harapan-harapan karyawan tersebut tidak dapat terpenuhi, maka akan mampu mempengaruhi keputusan-keputusan karyawan tentang seberapa puas mereka terhadap pekerjaannya.

Sesuai dengan Discrepancy Theory yang diungkapkan oleh Porter bahwa mengukur kepuasan kerja dengan menghitung selisih antara apa yang karyawan harapkan dengan kenyataan yang mereka rasakan atau yang mereka dapatkan saat ini. ${ }^{(6)}$

Hasil penelitian yang dilakukan oleh Wiliam M Mercer (2012) terhadap 206 perusahaan menengah dan besar yang memiliki tingkat perputaran karyawan yang tinggi. Menemukan bahwa kompensasi adalah alasan paling utama untuk ketidak puasan. Beberapa perusahaan dengan perputaran karyawan yang rendah $40 \%$ responden merasakan bahwa faktor emosional (kepuasan kerja, hubungan baik dengan manajer dan karyawan lain serta memotivasi mereka untuk tetap tinggal diperusahaan tersebut. sedangkan $21 \%$ responden lainnya menunjukan faktor finansialah yang memotivasi mereka tetap tinggal diperusahaan tersebut. ${ }^{(7)}$

Permasalahan pekerjaan yang sering muncul dibidang kesehatan khususnya di Dinas Kesehatan Provinsi Jambi adalah kualitas dan kuantitas ketenagaan yang terjadi, Oleh karena itu, peneliti melakukan studi pendahuluan melalui wawancara kepada pegawai Dinkes Prov. Jambi pada tanggal 0406 Januari 2016. Dari wawancara tersebut diperoleh beberapa informasi dan apa yang dirasakan oleh pegawai Dinkes Prov. Jambi bahwa faktor promosi jabatan sering berjalan tidak sesuai dengan paradigma kepangkatan dalam kedinasan serta adanya status kekerabatan yang mengarah pada kesenjangan kerja dan jabatan yang ditempati bukan pada pegawai yang dpromosikan tetapi pada orang yang memiliki kepentingan individual. Promosi jabatan memfokuskan pendidikan, kemampuan dan pengalaman kerja untuk berprestasi. Jika elaborasi tersebut bersifat positif maka kemungkinan akan berdampak pada peningkatan kerja, akan tetapi sebaliknya jika hasil elaborasinya negatif maka akan berdampak pada kemunduran kinerja dan mempengaruhi kepuasan kerja pada pegawai Dinkes Provinsi Jambi.

Faktor yang juga dirasakan oleh pegawai Dinas Kesehatan Provinsi Jambi adalah pembagian tugas dan beban kerja pegawai yang tidak merata sehingga menimbulkan kecemburuan sesama pegawai. disatu sisi ada beberapa pegawai yang selalu melaksanakan pekerjaan sampai overtime (lembur) tapi disisi lain terdapat pegawai yang tidak mempunyai pekerjaan (sangat santai).

Begitu pula halnya dengan faktor keadilan pembagian insentif lebih ditingkatkan lagi sehingga dapat diseimbangkan antara pemberian insentif finansial dan insentif non finansial, dari hasil wawancara, pegawai menyatakan bahwa ternyata pemberian insentif non finansial dirasa kurang diberikan kepada pegawai, pegawai menyatakan bahwa tidak hanya insentif finansial saja yang diperlukan namun juga dari segi pemberian insentif non finansial yang berupa ucapan terima kasih, penghargaan formal maupun informal, dan juga pujian lisan maupun tulisan kepada pegawai yang dapat menyelesaikan pekerjaan dengan baik. Hal tersebut diharapkan menambah kepuasan pegawai Dinas Kesehatan Provinsi Jambi dalam bekerja.

Perumusan masalah dalam penelitian ini adalah semakin menurunnya tingkat kepuasan kerja karyawan dari waktu ke waktu karena faktor promosi jabatan sering berjalan tidak sesuai dengan paradigma kepangkatan dalam kedinasan, faktor pembagian tugas dan beban kerja pegawai yang tidak merata sehingga menimbulkan kecemburuan sesama pegawai serta faktor keadilan pembagian insentif yang perlu ditingkatkan lagi. Oleh karena itu tujuan dari penelitian ini adalah untuk mengetahui pengaruh promosi kenaikan jabatan, efektifitas pembagian tugas dan keadilan pembagian insentif terhadap kepuasan kerja pegawai di kantor Dinkes Provinsi Jambi.

Berdasarkan hal tersebut diatas maka peneliti tertarik meneliti pengaruh promosi 
kenaikan jabatan, efektifitas pembagian tugas, dan keadilan pembagian insentif terhadap kepuasan pegawai Dinas Kesehatan Provinsi Jambi.

\section{Metode Penelitian}

Jenis penelitian yang digunakan adalah observasional dengan menggunakan metode survei (kuantitatif). Pendekatan dalam penelitian ini adalah Cross-Sectional dimana pengamatan dilakukan dalam satu waktu atau satu periode tertentu dengan ciri setiap subyek hanya diamati satu kali saja atau mengadakan pengamatan sekali saja terhadap beberapa variabel dalam satu waktu bersamaan.

Populasi penelitian ini adalah karyawan Dinkes Provinsi Jambi yang berjumlah 277. Pengambilan sampel pada penelitian ini menggunakan teknik proportional random sampling berdasarkan bidang, yaitu pengambilan sampel dimana sampel diambil secara proporsional sesuai jumlah karyawan tiap bidang ada. Besar sampel penelitian ini sebanyak 74 sampel

Data yang diambil dalam penelitian ini adalah data primer melalui kuisioner terstruktur. Skala yang digunakan adalah skala Likert dengan rentang skala 1 sampai 5. Data penelitian diolah secara kuantitatif dengan metode univariat, bivariat dengan uji Chi Square dan analisis multivariat dengan analisis regresi logistik.

\section{Hasil}

Analisis Univariat

Kepuasan (Variabel Terikat: Y)

Distribusi responden berdasarkan kepuasan di Dinkes Provinsi Jambi yang sudah dikatagorikan menjadi tidak puas dan puas dapat dilihat dalam tabel 1 dibawah ini.

Berdasarkan tabel 1 terlihat bahwa sebagian besar responden merasakan kepuasan dalam kerja $(56,8 \%)$, sedangkan lainnya merasakan ketidakpuasan dalam kerja $(43,2 \%)$. Hasil ini menunjukkan sebagian besar pegawai merasa puas terhadap aspekaspek dalam pekerjaan. Apa yang dirasakan oleh pegawai dengan apa yang diharapkan sudah sesuai, sehingga menimbulkan kepuasan. Kepuasan yang dirasakan diakibatkan sesuainya harapan pegawai terhadap aspek-aspek dalam pekerjaan, seperti promosi jabatan, gaji/upah, manajemen dan kepemimpinan.

Promosi Kenaikan Jabatan (Variabel Bebas: $\mathrm{X} 1)$

Distribusi responden berdasarkan promosi kenaikan jabatan di Dinkes Provinsi Jambi yang sudah dikategorikan menjadi kurang dan baik dapat dilihat dalam tabel 2 dibawah ini.

Berdasarkan tabel 2 terlihat bahwa proporsi responden yang mempersepsikan promosi kenaikan jabatan baik dan kurang adalah seimbang (50\%). Hal ini menunjukkan promosi kenaikan jabatan dipersepsikan beragam oleh pegawai, ada yang menganggap promosi yang dilakukan oleh Dinkes Provinsi Jambi sudah berjalan dengan baik dan efektif, sebagian pegawai merasa belum baik.

Efektivitas Pembagian Tugas (Variabel Bebas: $\mathrm{X} 2$ )

Distribusi responden berdasarkan efektivitas pembagian tugas di Dinkes Provinsi Jambi yang sudah dikategorikan menjadi kurang dan baik dapat dilihat dalam tabel 3 dibawah ini.

Berdasarkan tabel 3 terlihat bahwa sebagian besar responden mempersepsikan efektivitas pembagian tugas adalah baik $(55,4 \%)$, sedangkan lainnya mempersepsikan efektivitas pembagian tugas kurang $(44,6 \%)$. Hasil ini mengindikasikan bahwa pembagian tugas di Dinkes Provinsi Jambi sudah berjalan efektif. Artinya, pembagian kerja sudah terselenggara dengan baik sesuai rencana dan tujuan yang ingin dicapai, sehingga pegawai lebih bertanggung jawab atas terselenggaranya pekerjaan tersebut.

Keadilan Pembagian Insentif (Variabel Bebas: X3)

Distribusi responden berdasarkan keadilan pembagian insentif di Dinkes Provinsi Jambi yang sudah dikategorikan menjadi kurang dan baik dapat dilihat dalam tabel 4 dibawah ini.

Berdasarkan tabel 4 terlihat bahwa sebagian besar responden mempersepsikan keadilan pembagian insentif adalah baik $(51,4 \%)$, sedangkan lainnya mempersepsikan keadilan pembagian insentif secara kurang (48,6\%). Hal ini menunjukkan bahwa pembagian insentif di lingkungan Dinkes 
Provinsi Jambi sudah berjalan dengan adil. Pembagian insentif di Dinkes Provinsi Jambi dilakukan sesuai dengan aturan yang berlaku, baik peraturan perundang-undangan maupun perda.

Analisis Bivariat

Hubungan Promosi Kenaikan Jabatan dengan Kepuasan Pegawai

Hasil analisa hubungan antara promosi kenaikan jabatan dengan kepuasan pegawai Dinkes Provinsi Jambi disajikan dalam tabel 5.

Berdasarkan analisa crosstab pada tabel 5 diketahui responden yang tidak puas lebih banyak pada responden yang mempersepsikan kurang terhadap promosi kenaikan jabatan $(62,2 \%)$ dibandingkan yang mempersepsikan baik terhadap promosi kenaikan jabatan (24,3\%), sedangkan responden yang puas lebih banyak pada responden yang mempersepsikan baik terhadap promosi kenaikan jabatan $(75,7 \%)$ dibandingkan yang mempersepsikan kurang terhadap promosi kenaikan jabatan $(37,8 \%)$. Dengan demikian, promosi kenaikan jabatan yang berjalan secara baik dan efektif akan meningkatkan kepuasan pegawai.

Berdasarkan hasil pengujian $C h i$ Square didapatkan nilai $\mathrm{p}=0,001(\mathrm{p}<0,05)$, sehingga dapat disimpulkan bahwa ada hubungan yang bermakna antara promosi kenaikan jabatan dengan kepuasan pegawai Dinkes Provinsi Jambi. Hasil penelitian ini sejalan dengan penelitian yang dilakukan oleh Nugraha dan Surya (2016) yang berjudul "Pengaruh Kompensasi, Lingkungan Kerja dan Promosi Jabatan Terhadap Kepuasan Kerja", yang menunjukkan bahwa promosi jabatan berpengaruh positif dan signifikan terhadap kepuasan kerja karyawan PT. TELKOM wilayah Bali Selatan. Promosi jabatan merupakan faktor yang dilihat oleh karyawan sebagai salah satu penyebab kepuasan kerja. ${ }^{(8)}$

Robbins menyebutkan bahwa kesempatan untuk memperoleh promosi melalui jenjang kepangkatan mempengaruhi kepuasan kerja karyawan. Kepuasan kerja mempengaruhi produktivitas kerja karyawan, dengan demikian untuk meningkatkan produktifitas kerja karyawan perlu memperhatikan kepuasan kerja karyawan. ${ }^{(9)}$ Hubungan Efektivitas Pembagian Tugas dengan Kepuasan Pegawai

Hasil analisa hubungan antara efektivitas pembagian tugas dengan kepuasan pegawai Dinkes Provinsi Jambi disajikan dalam tabel 6 .

Tabel 1. Distribusi Frekuensi Kepuasan

\begin{tabular}{llcc}
\hline & Kepuasan & Jumlah & Persentase \\
\hline 1. Tidak Puas & 32 & 43,2 \\
2. Puas & 42 & 56,8 \\
\hline \multicolumn{2}{r}{ Total } & 74 & 100.0 \\
\hline
\end{tabular}

Tabel 2. Distribusi Frekuensi Promosi Kenaikan Jabatan

\begin{tabular}{|c|c|c|}
\hline Promosi Kenaikan Jabatan & Jumlah & Persentase \\
\hline 1. Kurang & 37 & 50,0 \\
\hline 2. Baik & 37 & 50,0 \\
\hline Total & 74 & 100.0 \\
\hline
\end{tabular}

Tabel 3. Distribusi Frekuensi Efektivitas Pembagian Tugas

\begin{tabular}{|c|c|c|}
\hline Efektivitas Pembagian Tugas & Jumlah & Persentase \\
\hline 1. Kurang & 33 & 44,6 \\
\hline 2. Baik & 41 & 55,4 \\
\hline Total & 74 & 100.0 \\
\hline
\end{tabular}


Tabel 4. Distribusi Frekuensi Keadilan Pembagian Insentif Keadilan Pembagian Insentif Jumlah Persentase

\begin{tabular}{llcc} 
1. Kurang & 36 & 48,6 \\
2. Baik & & 38 & 51,4 \\
\hline & Total & 74 & 100.0 \\
\hline
\end{tabular}

Tabel 5. Hubungan antara Promosi Kenaikan Jabatan dengan Kepuasan Pegawai Dinkes Provinsi Jambi

\begin{tabular}{lcccccc}
\hline \multirow{3}{*}{ Promosi Kenaikan Jabatan } & \multicolumn{4}{c}{ Kepuasan } & \multirow{2}{*}{ Nilai $\mathrm{p}$} \\
\cline { 2 - 5 } & \multicolumn{3}{c}{ Tidak Puas } & \multicolumn{2}{c}{ Puas } & \\
\cline { 2 - 5 } & $\mathrm{f}$ & $\%$ & $\mathrm{f}$ & $\%$ & \\
\hline 1. Kurang & 23 & 62,2 & 14 & 37,8 & \multirow{2}{*}{0,001} \\
2. Baik & 9 & 24,3 & 28 & 75,7 & \\
\hline
\end{tabular}

Tabel 6. Hubungan antara Efektivitas Pembagian Tugas dengan Kepuasan Pegawai Dinkes Provinsi Jambi

\begin{tabular}{lcccccc}
\hline & \multicolumn{4}{c}{ Kepuasan } & \multirow{2}{*}{ Nilai $\mathrm{p}$} \\
\cline { 2 - 5 } Efektivitas Pembagian Tugas & \multicolumn{2}{c}{ Tidak Puas } & \multicolumn{2}{c}{ Puas } & \\
\cline { 2 - 5 } & $\mathrm{f}$ & $\%$ & $\mathrm{f}$ & $\%$ & \multirow{2}{*}{0,007} \\
\hline 1. Kurang & 20 & 60,6 & 13 & 39,4 & \\
2. Baik & 12 & 29,3 & 29 & 70,7 & \\
\hline
\end{tabular}


Berdasarkan analisa crosstab pada tabel 6 diketahui responden yang tidak puas lebih banyak pada responden yang mempersepsikan kurang terhadap efektivitas pembagian tugas $(60,6 \%)$ dibandingkan yang mempersepsikan baik terhadap efektivitas pembagian tugas $(29,3 \%)$, sedangkan responden yang puas lebih banyak pada responden yang mempersepsikan baik terhadap efektivitas pembagian tugas $(70,7 \%)$ dibandingkan yang mempersepsikan kurang terhadap efektivitas pembagian tugas $(39,4 \%)$. Dengan demikian, pembagian tugas-tugas pegawai secara efektif dapat meningkatkan kepuasan pegawai.

Berdasarkan hasil pengujian $C h i$ Square didapatkan nilai $\mathrm{p}=0,007(\mathrm{p}<0,05)$, sehingga dapat disimpulkan bahwa ada hubungan yang bermakna antara efektivitas pembagian tugas dengan kepuasan pegawai Dinkes Provinsi Jambi. Hasil penelitian mendukung penelitian yang dilakukan oleh Rozi (2005) yang berjudul "Faktor-Faktor yang Berkaitan dengan Kepuasan Kerja Karyawan Tata Usaha Politeknik Kesehatan Bengkulu", yang menunjukkan bahwa salah satu sumber ketidakpuasan responden adalah gaji dan penempatan yang tidak sesuai dengan pendidikan.

Untuk melaksanakan serangkaian tugas, wewenang dan tanggung jawab, setiap organisasi atau perusahaan perlu menerapkan asas pembagian tugas atau kerja dengan cara memerinci dan mengelompokan aktifitas yang semacam atau erat hubugannya satu sama lainnya untuk dilakukan oleh karyawannya. Pembagian tugas menggambarkan sejauh mana tugas-tugas dalam organisasi dibagibagi kedalam beberapa pekerjaan tersendiri.

Hubungan Keadilan Pembagian Insentif dengan Kepuasan Pegawai

Hasil analisa hubungan antara keadilan pembagian insentif dengan kepuasan pegawai Dinkes Provinsi Jambi disajikan dalam tabel 7.

Berdasarkan analisa crosstab pada tabel 7 diketahui responden yang tidak puas lebih banyak pada responden yang mempersepsikan kurang terhadap keadilan pembagian insentif $(61,1 \%)$ dibandingkan yang mempersepsikan baik terhadap keadilan pembagian insentif (26,3\%), sedangkan responden yang puas lebih banyak pada responden yang mempersepsikan baik terhadap keadilan pembagian insentif $(73,7 \%)$ dibandingkan yang mempersepsikan kurang terhadap keadilan pembagian insentif $(38,9 \%)$ Dengan demikian, pembagian insentif yang dilakukan secara adil menurut persepsi pegawai akan memuaskan para pegawai itu sendiri.

Berdasarkan hasil pengujian Chi Square didapatkan nilai $\mathrm{p}=0,003(\mathrm{p}<0,05)$, sehingga dapat disimpulkan bahwa ada hubungan yang bermakna antara keadilan pembagian insentif dengan kepuasan pegawai Dinkes Provinsi Jambi. Hasil penelitian ini sesuai dengan penelitian Ardini (2013) dengan judul "Hubungan Persepsi Keadilan Kompensasi dengan Kepuasan Kerja pada Karyawan PT. Agus Jaya Mojokerto", yang menunjukkan persepsi keadilan kompensasi memiliki hubungan yang positif dengan kepuasan. Kompensasi yang diberikan secara adil dan layak sesuai dengan tanggung jawab karyawan sangat berhubungan dengan tingkat kepuasan kerja karyawan. (10) Penelitian ini juga didukung oleh penelitian Nugraha dan Surya (2016) yang menunjukkan kompensasi berpengaruh secara signifikan terhadap kepuasan kerja. Faktor kompensasi, termasuk didalamnya adalah insentif, mempunyai pengaruh terhadap kepuasan kerja karyawan karena kompensasi yang sesuai dengan beban kerja yang diberikan kepada karyawan dapat memberikan rasa nyaman dan interaksi yang baik antara karyawan dan atasan. ${ }^{(8)}$

Judge menyatakan bahwa gaji atau insentif berpengaruh secara positif terhadap kepuasan kerja. Pada dasarnya seseorang bekerja mengharapkan imbalan yang sesuai dengan jenis pekerjaannya. Karena adanya imbalan yang sesuai dengan pekerjaannya, maka akan timbul pula rasa gairah kerja yang semakin baik, imbalan dari kerja bermacammacam bentuk, tak selalu tergantung pada uang. Imbalan adalah hal-hal yang mendorong tenaga kerja untuk bekerja lebih giat. ${ }^{(11)}$ 
Analisis Multivariat

Hasil uji regresi logistik multivariat dengan menggunakan metode Enter dapat dilihat pada tabel 8 .

Dari hasil analisis multivariat, variabel dikatakan signifikan jika nilai $\mathrm{p}<0,05$. Terdapat dua variabel bebas dengan nilai $\mathrm{p}<$ 0,05 , yaitu promosi kenaikan jabatan dan keadilan pembagian insentif, artinya variabel tersebut merupakan faktor yang berpengaruh terhadap kepuasan pegawai. Dengan demikian, variabel promosi kenaikan jabatan dan keadilan pembagian insentif secara bersamasama berpengaruh terhadap kepuasan pegawai Dinkes Provinsi Jambi.

Berdasarkan hasil analisis multivariat, maka dapat dijelaskan sebagai berikut:

Diketahui nilai OR variabel promosi kenaikan jabatan sebesar 3,887, artinya responden yang mempersepsikan baik terhadap promosi kenaikan jabatan lebih berpeluang untuk merasa puas dalam bekerja sebesar 3,887 kali dibandingkan responden yang mempersepsikan kurang terhadap promosi kenaikan jabatan.

Diketahui nilai OR variabel keadilan pembagian insentif sebesar 3,212, artinya responden yang mempersepsikan baik terhadap keadilan pembagian insentif lebih berpeluang untuk merasa puas dalam bekerja sebesar 3,212 kali dibandingkan responden yang mempersepsikan kurang terhadap keadilan pembagian insentif.

Dengan demikian, variabel promosi kenaikan jabatan dan keadian pembagian insentif secara bersama-sama berpengaruh terhadap kinerja pegawai Dinkes Provinsi Jambi. Maka dari itu, untuk meningkatkan kepuasan pegawai dalam rangka peningkatan kinerja, perlu diperhatikan faktor-faktor tersebut. Artinya pelaksanaan promosi kenaikan jabatan secara adil dan terbuka serta pembagian insentif secara adil menjadi faktor utama yang perlu mendapatkan perhatian dari manajemen Dinkes Provinsi Jambi.

Kesimpulan

Berdasarkan hasil penelitian, gambaran dari kepuasan kerja dan faktorfaktor yang mempengaruhinya adalah sebagai berikut:

Sebagian besar responden merasakan kepuasan dalam kerja $(56,8 \%)$. Proporsi responde yang mempersepsikan promosi kenaikan jabatan baik dan kurang adalah seimbang $(50 \%)$. Sebagian besar responden mempersepsikan efektivitas pembagian tugas adalah baik $(55,4 \%)$ dan mempersepsikan keadilan pembagian insentif juga baik (51,4\%).

Ada hubungan yang bermakna antara promosi kenaikan jabatan, efektivitas pembagian tugas dan keadilan pembagian insentif dengan kepuasan pegawai Dinkes Provinsi Jambi.

Hasil analisis regresi logistik multivariat diketahui variabel promosi kenaikan jabatan dan keadilan pembagian insentif secara bersama-sama berpengaruh terhadap kepuasan pegawai Dinkes Provinsi Jambi

Tabel 7. Hubungan antara Keadilan Pembagian Insentif dengan Kepuasan Pegawai Dinkes Provinsi Jambi

\begin{tabular}{llccccc}
\hline \multirow{3}{*}{ Keadilan Pembagian Insentif } & \multicolumn{5}{c}{ Kepuasan } & \multirow{2}{*}{ Nilai $\mathrm{p}$} \\
\cline { 2 - 5 } & \multicolumn{3}{c}{ Tidak Puas } & \multicolumn{2}{c}{ Puas } & \\
\cline { 2 - 5 } & $\mathrm{f}$ & $\%$ & $\mathrm{f}$ & $\%$ & \\
\hline 1. Kurang & 22 & 61,1 & 14 & 38,9 & \multirow{2}{*}{0,003} \\
2. Baik & 10 & 26,3 & 28 & 73,7 & \\
\hline
\end{tabular}

Tabel 8. Hasil Analisis Multivariat

\begin{tabular}{c|lccccc}
\hline Step & \multicolumn{1}{c}{ Variabel } & B & Nilai $p$ & OR & \multicolumn{2}{c}{ 95\% CI } \\
\cline { 5 - 7 } & & & & & Lower & Upper \\
\hline \multirow{2}{*}{1} & Promosi Kenaikan Jabatan & 1,315 & 0,015 & 3,724 & 1,286 & 10,785 \\
& Efektivitas Pembagian Tugas & 0,738 & 0,207 & 2,093 & 0,665 & 6,585 \\
& Keadilan Pembagian Insentif & 0,848 & 0,151 & 2,335 & 0,733 & 7,436 \\
\hline
\end{tabular}




\begin{tabular}{l|lccccc}
2 & Promosi Kenaikan Jabatan & 1,358 & 0,011 & 3,887 & 1,360 & 11,109 \\
& Keadilan Pembagian Insentif & 1,167 & 0,029 & 3,212 & 1,129 & 9,138 \\
\hline
\end{tabular}

\section{Daftar Pustaka}

1 Dinkes Provinsi Jambi. Rencana Strategis Dinas Kesehatan Provinsi Jambi Tahun 2010-2015 (Renstra).

2. Moekijat. Manajemen Kepegawaian (Personal Managemen). Bandung : CV. Alfabeta, 2007.

3. Sulistiyani, AT. Memahami Good Governance Dalam Prespektif Sumber Daya Manusia. Yogyakarta : Gaya Media; 2011.

4. Undang-Undang Republbik Indonesia Nomor 5 Tahun 2014 tentang Aparatur Sipil Negara (ASN).

5. Zaputri, RA, Rahardjo, $\mathrm{K}$ and Utami, NH. Pengaruh Insentif Material dan Non Material terhadap Kepuasan Kerja dan Kinerja Karyawan: Studi pada Karyawan Produksi Cetak PT. Temprina Media Grafika di Surabaya.. 2013, Jurnal Manajemen, Strategi Bisnis dan Kewirausahaan, Agustus 2013:vol.7 (2)

6. Porter, DE and Applewhite, PB. Studies in Organizational Behaviour and Management. New York : International Textbook Company ; 2000.

7. Mercer, Wiliam M. Meningkatkan Kepuasan Karyawan dan Mengurangi Perputaran Karyawan. [Online] [Dikutip: 5 Oktober 2012.] http://www.oxfofduniversity.com.

8. Nugraha, Made Bayu Indra and Surya, Ida Bagus Ketut. Pengaruh Kompensasi, Lingkungan Kerja dan Promosi Jabatan terhadap Kepuasan Kerja. 2016, EJurnal Manajemen Unud, Vol. 5 (1), pp. 59-87.

9. Robbins, SP. Perilaku Organisasi Sumber Daya Manusia. Jakarta : PT. Prenhallindo;2006.
10. Ardini, Pradnya Dahniar. Hubungan Persepsi Keadilan Kompensasi dengan Kepuasan Kerja pada Karyawan PT. Agus Jaya Mojokerto. Malang : Universitas Negeri Malang, 2013, Artikel.

11. Federick Hezberg, Manajemen Sumber Daya Manusia Untuk Perusahaan. Jakarta : PT. Bumi Aksara ; 2006

12. Mathis, Robert L and Jackson, JH. Human Resource Management. s.1. : Thomson Learning South-Western College Publishing; 2006.

13. Cue, Mc and Gerasimos, A. Ginarkis. The Relationship Betwen Job Satisfaction and Performance. 2007, Publik Produktivity \& Management Review.

14. Robbins, SP. Perilaku Organisasi: Konsep, Kontroversi dan Aplikasi. Jakarta : PT. Prenhallindo, 2001.

15. Nitisemito, Alex S. Manajemen Personalia dan Sumber Daya Manusia. Jakarta : Ghalia Indonesia, 2002.

16. Hasibuan, Malayu SP. Manajemen Sumber Daya Manusia. Jakarta : PT. Bumi Aksara, 2010.

17. Wursanto, IG. Dasar-dasar Manajemen. Jakarta : Pustaka Dian; 2003.

18. Sutarto. Dasar-dasar Organisasi dan Manajemen. Jakarta : Ghalia Indonesia; 2006.

19. Samsudin, Sadili. Manajemen Sumber Daya Manusia. Bandung : Pustaka Setia; 2006.

20. Mangkunegara, Anwar Prabu. Evaluasi Kinerja SDM. Bandung : Refika Aditama; 2006.

21. Handoko, $\mathrm{T}$ Hani. Manajemen Personalia dan Sumber Daya Manusia. Yogyakarta : BPFE; 2009.

22. Sudarmo, Gito. Perilaku Organisasi. Yogyakarta : BPFE; 2007. 